\title{
Novel Bagaton dan Ngayau: Satu Analisis Menerusi Kaca Mata Gagasan Persuratan Baru
}

\author{
${ }^{1}$ ASMIATY AMAT \\ ${ }^{2}$ LOKMAN ABDUL SAMAD \\ ${ }^{I}$ Pusat Penataran Ilmu \& Bahasa, UMS, ${ }^{2}$ Fakulti Kemanusiaan, Seni dan Warisan, UMS, \\ Jln. UMS, 8400 Lota Kinabalu, Sabah, Malaysia. \\ 'adajiwa@gmail.com,.2lokns@yahoo.com
}

\begin{abstract}
Abstrak Novel Bagaton dan Ngayau merupakan karya Ismail Abbas atau Amil Jaya. Sunguhpun kedua-dua novel ini bukan novel Islam, sedikit sebanyak ia memperlihatkan inti pati berkaitan persoalan keagamaan yang dihadapi oleh masyarakat pelbagai etnik di negeri Sabah dan Sarawak pada satu ketika dalam gambaran yang dibawakan oleh penulis. Kajian ini akan menggunakan Gagasan Persuratan Melayu Baru yang dicetuskan Mohd. Affandi Hassan dan diberikan perhatian serius oleh Ungku Maimunah Mohd. Tahir dan Mohd. Zariat Abdul Rani. Kajian ini mendapati bahawa penulis dengan kesedarannya cuba berdakwah dan menonjol serta mempertahankan kesucian agama Islam melalui persoalan yang digambarkan dalam karya. Namun demikian, terdapat bahagian-bahagian tertentu yang memperlihatkan ia terlepas pandang dan menenggelamkan keseluruhan gambaran dakwah yang cuba ditonjolkan penulis.
\end{abstract}

Kata kunci: Bagaton, Ngayau, Persuratan Baru, dakwah, Islam, Sabah

Abstract Bagaton and Ngayau are novels by Ismail Abbas who also goes by this pen name Amil Jaya. Both novels depict issues about religion faced by the various ethnic groups in Sabah and Sarawak. This study uses the new concepts in the New Malay Literature espoused by Mohd. Affandi Hasan, and given serious attention by Ungku Maimunah Mohd. Tahir and Mohd. Zariat Abdul Rani. Ismail Abbas's conscience can be seen in his novels where he tried to preach, portray and defend Islam through the issues depicted in them. However, there are certain parts that showed he missed the picture, and submerged the entire missionary message that the author wished to portray.

Keywords: Bagaton, Ngayau, New Literature, evangelism, Islamic, Sabah 


\section{PENGENALAN}

Bagaton dan Ngayau merupakan dua buah novel nukilan Ismail Abbas atau lebih dikenali sebagai Amil Jaya. Beliau merupakan penulis dari etnik Bajau (Sama') beragama Islam. Oleh itu, dapat dikatakan beliau sedia peka terhadap kesusasteraan Melayu yang antaranya berakar umbi daripada tradisi Islam. Kegiatan kreatif Amil Jaya berkembang dalam persekitaran tanah kelahirannya serta tempat beliau menuntut ilmu di Semenanjung Malaysia. Persekitaran ini memungkinkan Amil Jaya hadir sebagai seorang penulis yang peka terhadap adat resam dan budaya tempatan, termasuk isu serta perkembangan semasa yang berlaku dalam masyarakat Borneo, sama ada di Sabah mahupun Sarawak. Penting untuk dijelaskan bahawa dalam perkembangan semasa, Islam merupakan agama yang menjadi anutan masyarakat peribumi di kedua-dua negeri ini. Dengan konteks ini, maka tidak menghairankan jika cerita dalam novel Bagaton dan Ngayau dilihat cenderung mengutarakan nilai-nilai keislaman, sebagaimana yang akan diperlihatkan dalam analisis nanti. Pada tahap ini, memadai dikatakan bahawa kecenderungan Bagaton dan Ngayau terhadap Islam mendorong kajian ini untuk memanfaatkan Gagasan Persuratan Baru (seterusnya GPB) sebagai kerangka bagi menganalisis kedua-dua novel Amil Jaya ini. Pilihan ini didasarkan kepada hakikat bahawa GPB sendiri memang merupakan satu kerangka analisis karya sastera yang berteraskan Islam. Dengan menerapkan GPB, kajian ini berusaha untuk menganalisis serta menilai elemen-elemen dakwah yang diterapkan, dengan memberikan fokus terhadap soal bagaimana persoalan dimanifestasikan melalui perwatakan serta tindak-tanduk watak-watak dalam kedua-dua novel Amil Jaya ini.

\section{LATAR BELAKANG PENULIS DAN CERITA}

Ismail Abbas yang lebih dikenali sebagai Amil Jaya ialah sasterawan dan budayawan tempatan Sabah yang terkenal dengan novel-novel budaya. Novel Ngayau merupakan novel yang telah memenangi hadiah pertama peraduan mengarang novel anjuran GAPURA (Gabungan Penulis Sedar) dengan kerjasama Biro Bahasa Sabah pada tahun 1977. Novel ini merupakan percubaan kedua Ismail Abbas selepas beliau menang tempat kedua dalam peraduan menulis novel anjuran BAHASA (Badan Bahasa Sabah) pada 
tahun 1973 menerusi novel Cerah. Novel Bagaton pula adalah novel ketiga beliau yang ditulis pada tahun 1988. Berdasarkan dua kejayaan berturut-turut tersebut, Amil Jaya telah menempatkan dirinya pada satu kedudukan yang kukuh ketika itu, sekali gus telah dinobatkan sebagai penerima anugerah Sea Write Awards di Thailand pada tahun 1992.

Ismail Abbas dilahirkan di negeri Sabah dan pernah berkhidmat di Sarawak. Kedua-dua negara tersebut terletak di Kepulauan Borneo memiliki jumlah etnik paling ramai. Kepelbagaian itu membentuk variasi budaya, adat resam dan kepercayaan beragama. Negeri Sarawak dihuni oleh masyarakat Dayak yang terpecah pula kepada subetnik seperti Iban, Kelabit, Kenyah, Kayan selain Bidayuh, orang Melanau, Orang Melayu dan Lundayeh. Negeri Sabah pula dihuni oleh entik seperti Bajau yang terdiri daripada Bajau Darat dan Bajau Laut, Dusun yang memiliki pelbagai subetnik seperti Lotud, Tindal dan Kimaragang; Suluk; Iranun; Murut dan etnik lain seperti Tidong; Kokos dan Bugis. Pada masa dahulu, sebahagian besar etnik peribumi di Sabah seperti Dusun dan Murut dan Dayak di Sarawak mengamalkan kepercayaan animisme. Namun pada masa kini, kebanyakan daripada masyarakat peribumi kedua-dua negeri telah memeluk agama Islam atau Kristian. Pengarang menggunakan latar belakang Sabah dan Sarawak serta kepelbagaian etnik yang terdapat di dalamnya untuk dijadikan latar dalam karya-karya beliau. Novel Bagaton yang berlatar belakang negeri Sabah dan menggunakan watak orang Sama' (Bajau) dan Idaan (Dusun), sementara Ngayau menggunakan watak dari kalangan orang Kayan dan Melanau di Sarawak.

\section{NARATIF BAGATON DAN NGAYAU}

Bagaton menggambarkan kehidupan etnik Bajau dan Dusun di daerah Kota Belud, Sabah. Cerita berfokus pada kehidupan Jamjin, seorang lelaki keturunan Bajau yang berasal dari Kampung Pirasan. Dia ditakdirkan jatuh cinta dengan Punti yang berketurunan Dusun. Jamjin beragama Islam sementara Punti lahir dalam keluarga yang berpegang kuat kepada kepercayaan animisme. Perkahwinan mereka ditentang atas alasan dendam dan berlainan agama. 
Akibat rancangan perkahwinan yang tidak direstui oleh kedua pihak keluarga, Jamjin dan Punti melarikan diri dan berkahwin. Konflik semakin memuncak apabila Punti ditakdirkan sakit dan meninggal dunia. Jamjin yang tidak ditemani sesiapa berhasrat untuk mengebumikan isterinya secara Islam dan memohon bantuan ayahnya, Imam Lagung. Pada masa yang sama, dia tetap memaklumkan kematian isteri kepada ayah dan bapa mentua, iaitu Maragang dan Sangkurad. Imam Lagung tidak mahu menerima jenazah Punti, sementara Maragang berkeras mahu anaknya dikebumikan mengikut kepercayaan mereka. Bermula daripada itu, tragedi rampasan dan pertumpahan darah digunakan sebagai strategi naratif dalam novel ini.

Ngayau menyuguhkan cerita berlatar hutan tebal negeri Sarawak memaparkan kehidupan sekumpulan masyarakat yang mengamalkan tradisi memburu kepala (ngayau). Amalan ngayau lebih tepat diertikan sebagai suatu strategi atau taktik peperangan. Lumrahnya, perbuatan menyerang berlaku apabila timbul situasi permusuhan antara dua atau lebih individu dan kumpulan manusia (Bilcher Bala \& Baszley Bee, 2002: 5).

Penceritaan Ngayau dimulakan dengan paparan kisah orang Dayak dari Suku Kayan Hulu yang ingin membina rumah panjang baharu. Bagi memastikan rumah yang bakal dibina menjadi kukuh, masyarakat memerlukan jasad dan tengkorak kepala manusia untuk diletakkan di tiang seri rumah panjang yang akan dibina. Penghulu Kanyau selaku tuai rumah panjang telah melantik Lasa Kulan sebagai ketua untuk 'mengayau' dan mencari kepala musuh mereka, terutama musuh ketat mereka, daripada suku kaum Kelabit. Dalam perjalanan ngayau, pahlawan-pahlawan Kayan seramai sembilan orang telah menyerbu bèberapa orang pemuda daripada etnik Melanau yang sedang berehat. Boyong dan rakan-rakannya sedang dalam perjalanan mengejar suku Dayak Kelabit yang telah melarikan kepala datuk mereka, Shariff Hamid. Orang Kayan hakikatnya tidak bermusuh dengan orang Melanau. Namun, disebabkan terdapat peluang di hadapan mata, maka mereka memilih untuk menyerang Boyong dan rakan-rakannya. 


\section{GAGASAN PERSURATAN MELAYU BARU}

Konsep Gagasan Persuratan Melayu Baru (GPB) dicetuskan oleh Mohd Affandi Hasssan (1992) dan mendapat perhatian yang serius daripada Ungku Maimunah Mohd. Tahir dan Mohd. Zariat Abdul Rani (2008). Gagasan Persuratan Baru merujuk kepada konsep ilmu yang benar dan menolak kriteria yang ada pada teori-teori Barat yang bertentangan dengannya.

GPB berdiri atas beberapa idea pokok yang menjadi ciri asasnya. Pertama, gagasan PB mengutamakan ilmu, pemikiran dan kebijaksanaan. Kedua, Persuratan Baru memakai gaya penulisan bercorak kesarjanaan tetapi indah. Gaya itu dikatakan ilmiah kerana isinya berasaskan ilmu; tanpa mengenepikan aspek keindahan. Ketiga, ia mengutamakan gagasan; membicarakan dengan mendalam gagasan tersebut dengan menggunakan watak-watak yang kuat, bermoral, beragama, berilmu, berkorban mencapai cita-cita luhur dan bukan mengutarakan watak yang kurang bijaksana. Keempat, GPB mengutamakan daya kreatif yang tinggi, terkawal dan beradab. Kerana itu hal-hal khurafat dan khayal tidak ada tempat dalam GPB.

Tiga perkara pokok daripada pendekatan tauhid daripada GPB ialah memberi penekanan kepada hakikat insan (the nature of man), hakikat ilmu (the nature of knowledge) dan hakikat serta fungsi sastera (the nature and functions of literature). Gagasan ini tentu sahaja menjadikan al-Quran sebagai pegangan untuk menulis karya kreatif. Sehubungan dengan itu, gagasan ini melihat hakikat ilmu dan amal dalam pengembangan sebuah karya daripada tiga sumber ilmu yang ada pada manusia, iaitu wahyu, akal dan pengalaman. Ketiga-tiga sumber ilmu ini harus diadun bersama untuk mengukuhkan idea dan pemikiran penulis dalam sebuah karya.

Pendidikan yang baik dan keilmuan yang tinggi bertujuan untuk mewujudkan hasil sastera yang memuatkan ilmu dan pemikiran masyarakat dengan cara mempertingkatkan kualiti diri. Hakikat dan fungsi sastera pula dilihat daripada hakikat insan yang seterusnya membawa kepada pemahaman penggunaan kalam yang diaplikasikan ke atas karya-karya kreatif. Hakikat tauhid yang menjadi dasar kepada ajaran Islam mengutamakan aspek 
intelektual, aspek akal daripada aspek emosi dan hawa nafsu kerana seniman Islam berkarya untuk mendapat keredaan Allah SWT. Hakikat tauhid menegaskan penghasilan karya mestilah berguna dari segi syarak dan akhlaknya. Karya yang baik sepatutnya mempunyai ciri-ciri yang tersebut di dalam al-Quran seperti ketakwaan, dakwah, bersifat pendidikan, kudus, berakhlak, berunsur nasihat, irshad, ihsan, berperikemanusiaan, kasih sayang, hikmat, falsafah dan ketuhanan.

Sifat sastera yang sebelum ini sering diguna pakai ialah keutamaan kepada perasaan atau emosi yang dicapai melalui naratif yang dilebihlebihkan (khayalan kreatif) dan tumpuan kepada aspek kejahatan dalam kehidupan manusia. Persuratan yang diasaskan kepada ilmu hanya memperakukan cerita-cerita yang mengajar soal kebaikan dan kebijaksanaan. Perkara yang diutamakan ialah hakikat ilmu yang betul yang di dalamnya dibincangkan tentang hakikat insan (supaya perwatakan yang ditonjolkan adalah konsep insan yang betul, hakikat amal (untuk memastikan perilaku manusia tidak kepada nafsu rendah seperti yang dilukiskan dalam karya sastera Barat) dan hakikat seni penulisan (kerana karya itu bersifat didaktik, bukan propaganda semata-mata) bagi menuju kebijaksanaan (Mohd Affandi Hassan et al., 2008). Sehubungan itu, beberapa prinsip yang ada dalam GPB akan digunakan untuk melihat novel Bagaton dan Ngayau. Kesemua prinsip itu pula akan dibincangkan sekali gus berdasarkan persoalan dan perwatakan watak utama dalam karya tersebut dan dikaitkan dengan konsep ilmu (wacana). Adakah kedua-dua novel mengutamakan cerita atau ilmu melalui penggemblengan alat-alat penceritaan yang digunakan pengarang?

\section{BAGATON DAN NGAYAU MELALUI KACA MATA GAGASAN PERSURATAN BARU}

Melihat konsep dan garis panduan GPB, tentu tidak adil jika keseluruhan cirinya yang lengkap dengan unsur ketauhidan dipasakkan dalam karya yang bukan bercirikan sastera Islam. Namun hakikatnya, penerapan gagasan tersebut ke atas kedua-dua novel adalah untuk meninjau pemahaman pengarang berkenaan beberapa perkara yang berkaitan dengan agama seperti menegakkan akidah-tauhid, penerapan nilai ilmu berkaitan agama seperti ijab Kabul dalam perkahwinan dan amalan-amalan (amal) lain yang ditonjolkan 
pengarang dalam karya-karyanya. Tentu sahaja penerapan berkenaan kebenaran ilmu dalam sebuah karya kreatif juga boleh dipertikaikan. Namun, segala hal yang berpusatkan kepada agama dan akhlak perlu diberikan dengan jelas sebagai satu seruan bahawa sastera itu bukan setakat membijaksanakan manusia tetapi sebagai satu wadah untuk menyebarkan maklumat yang tepat, lebih-lebih lagi yang berkaitan dengan agama.

Kedua-dua novel memperlihatkan bagaimana terdapat dua pasangan berlainan bangsa dan agama dapat bersatu sebagai pasangan suami isteri. Melalui perkahwinan antara dua bangsa dan kepercayaan yang berbeza, pengarang cuba menonjolkan unsur dakwah dalam kedua-dua novel. Sungguhpun tidak ada penjelasan lengkap bagaimana wanita bukan Islam tertawan dan jatuh hati kepada agama Islam lalu berkahwin, pengarang cuba memaparkan bagaimana watak Punti dalam Bagaton yang cinta dan berkahwin dengan Jamjin, seterusnya cinta kepada agama Islam. Ia tergambar dalam kenyataan Punti seperti berikut:

"Islam telah membahagiakan kehidupan kita bang, bisik Mawar perlahan.

“Sungguh?" Jamjin mengeratkan pelukannya.

"Aku terhindar daripada ketakutan dalam hidup. Islam seperti menjamin kehidupan saya," Mawar mendongak.

..."Syukur Alhamdulillah Ya Allah. Kekalkanla aku di dalam kepercayaan agamaMu ini," Mawar berdoa.

"Bagaimana kalau ayahmu datang menuntut engkau pulang?

Lindungilah saya daripada tuntutan itu bang. Demi Allah dan

RasulNya, saya tetap mengingkari tuntutan demikian...

(Bagaton, hlm. 122).

Berdasarkan hujah tersebut, ia menjelaskan tentang pengislaman dan kejujuran Punti yang melaksanakan tanggungjawabnya sebagai seorang Muslim sejati selepas memeluk agama Islam.

"Mawar sudah Islam ayah. Dia mengerjakan sembahyang lima waktu, berpuasa pada bulan Ramadan dan sering mengucapkan kalimah syahadah sejak dua tahun lalu. Saya tidak meragui keimanannya, ayah." Jamjin terus memohon simpati ayahnya (Bagaton, hlm. 77). 
Bagi pengarang, syarat memeluk agama Islam tidak semestinya dilakukan oleh imam atau orang berilmu pengetahuan agama. Memadai dengan mengucap dua kalimah syahadah dengan syarat-syarat (Kitab Sahih Muslim; Hadis 40 al-Nawawi, Hadis no. 2). Perkara ini menunjukkan bahawa pengarang mengetahui tentang syarat pengislaman bagi seorang yang ingin memeluk Islam sungguhpun Imam Lagung tidak menerima keislaman Punti. Sementara dari sudut perundangan dalam pentadbiran Islam, beberapa syarat perlu dilaksanakan bagi mengelak daripada berlaku pertikaian dan kecelaruan pada masa hadapan. Akibat pengislaman Punti yang tidak didaftarkan, Maragang sebagai ayah berhak menuntut mayat Punti setelah dia meninggal dunia. Dalam hal ini, konteks penulisan pengarang berlaku sebelum wujud Akta 505 Pentadbiran Undang-undang Islam 1993.

Penekanan konsep GPB yang bertunjangkan tauhid memberi penekanan kepada wacana bagi mengelakkan penulis mengaburi minda pembaca atau masyarakat dengan kepalsuan. Ikatan taklif dalam wacana dan penceritaan tidak memberi ruang kepada penulis untuk bercerita dan membentuk sensasi (Mohd. Affandi Hassan, 2008: 64 - 65). Menurut GPB, selain bertindak sebagai alat untuk berdakwah, sebuah karya wajar menampilkan atau menonjolkan undang-undang dan pelaksanaan hukum yang boleh dijadikan landasan pemikiran umat Islam. Berdasarkan hal ini GPB memperakukan keislaman Punti.

Selain daripada itu, pengarang turut memperlihatkan bagaimana Imam Lagung dan penduduk Kampung Pirasan akur dan melaksanakan hukum hudud. Menerusi novel ditonjolkan bagaimaana pelaksanaan hukum sebat ke atas pesalah zina dan diterima oleh pesalah berkenaan. Hal ini dinyatakan menjadi contoh terbaik yang diutarakan oleh penulis sebagai satu cara untuk memberi amaran, kesedaran dan pengajaran kepada orang yang menyaksikan hukuman tersebut. Pelaksanaan hukuman sebat dilakukan dengan penuh adil setelah mendengar empat orang saksi yang melihat perlakuan itu. Hal ini dijelaskan dalam novel, iaitu:

"Hari ini seorang lagi penzina akan dihukum," Imam Lagung menekankan. "Dari keterangan empat saksi yang melihat perlakuan itu dan disokong oleh keikhlasan pengakuan orang yang dituduh, 
nampaknya jelaslah si tertuduh sabit kesalahannya", Imam Lagung menarik nafas (Bagaton, hlm. 64).

Sebagai memenuhi watak seorang imam yang berpegang pada prinsip mengesakan Allah serta melaksanakan perintah agama, Imam Lagung digambarkan sebagai imam yang bertanggungjawab melaksanakan amanah Allah SWT. Ia amat sesuai dengan gagasan yang menonjolkan perspektif hakikat insan serta hakikat ilmu dan amal. GPB yang menjunjung pengertian 'ilmu yang benar' yang merujuk kepada ilmu yang berupaya menjadikan manusia mengenali penciptanya serta membawa mereka ke arah kebaikan dan meninggalkan kemungkaran (amar ma'ruf nahi mungkar) (Mohd. Affandi Hassan, 2008: 156). Dari segi hakikat insan pula, penekanan ibadah, lebih tepat untuk menjelaskan pendirian Imam Lagung sebagai hamba Allah SWT yang menjalankan tugasnya mengikut syariat Islam. Pada tahap ini, pengarang memperlihatkan bagaimana wacana Bagaton seiring dengan GPB. Hal ini dikesan melalui dialog berikut:

"Hukum Allah harus dilaksanakan, tidak harus ada tolak ansurnya. Kita menjalankan amanah yang diperintahkan oleh Allah. Elok kita laksanakan hukumannya sekarang," seorang jemaah mengusulkan.

(Bagaton, hlm. 85).

Seterusnya, ditonjolkan tentang permasalahan nikah kahwin dalam adab perkahwinan pasangan yang berlainan bangsa dan agama. Bagaimana cara pengarang menggembeleng isu tersebut dalam kedua-dua karya? Jamjin dan Punti yang telah jatuh cinta berhasrat untuk berkahwin. Ayah Punti tidak bersetuju dan menyebabkan Punti melarikan diri. Imam Lagung juga tidak mahu mengahwinkan mereka kerana menganggap Punti belum memeluk agama Islam. Naratif cerita menjelaskan bahawa keengganan Imam Lagung adalah berdasarkan sifat dendamnya terhadap Maragang, ayah Punti.

Oleh hal yang demikian, Jamjin telah melakukan pernikahan sendiri. Bagaimanakah cara pengarang melaksanakan perintah yang telah dinyatakan jelas dalam al-Quran berkenaan akad nikah yang dilaksanakan dalam kedua-dua karya berkenaan? Adakah pengarang mengikut garis panduan yang ditetapkan agama atau memilih untuk mensensasikan 'cerita' sebagai modal untuk melaksanakan tanggungjawab tersebut? 
Halangan dan keengganan ayahnya untuk bekerjasama yang merupakan seorang imam menyebabkan Jamjin dan Punti nekad meneruskan niat mereka. Kedua-duanya lari ke Kampung Lumatok dan berkahwin sendiri. Pengarang melanjutkan upacara akad nikah melalui petikan berikut:

"Kunikahkan diriku, Jamjin bin Lagung dengan Mawar anak Maragang (Punti) dengan maharnya sebilah keris." "Kuterima nikahnya Jamjin bin Lagung dengan maharnya sebilah keris"

(Bagaton, hlm. 76).

Rukun nikah dalam Islam ialah; pertama, ada pasangan yang akan bernikah; kedua, ada wali; ketiga, dua orang saksi dan; keempat sighah atau akad ijab kabul. Bagi perkahwinan Jamjin dan Punti (Mawar), mereka telah memenuhi rukun nikah yang pertama dan keempat. Jamjin menikahkan dirinya sendiri dengan Punti melalui ijab kabul sebagaimana dalam petikan. Namun demikian, mereka tidak mempunyai wali dan saksi. Pernikahan tersebut tidak sah kerana tidak memenuhi rukun nikah.

Kedua-dua pasangan yang belum cukup syarat nikah itu pula tinggal sebagai pasangan suami isteri dan tindakan tersebut menyamai perbuatan zina. Maka, menerusi GPB tindakan ini bukan setakat menyalahi akidah Muslim sejati - malah, perbuatan tersebut mendorong pembaca untuk terpengaruh dan mengulangi kesalahan yang sama.

Perkahwinan terhalang dan salah pula di sisi agama akhirnya mengundang tragedi. Naratif cerita sememangnya membangkitkan saspens dan sensasi. Plot yang berasaskan sebab dan akibat memaparkan episod kegagalan Jamjin mendapatkan pertolongan daripada ayahnya menyebabkan dia diserang oleh orang suruhan Maragang. Akhirnya Jamjin dan konco-konco Maragang mati dibunuh oleh 'Pengait.'Namun demikian, ilmu yang ingin disampaikan pengarang menyimpang daripada landasan Islam sebenar. Oleh itu, penekanan ilmu yang benar melalui GBP amat penting bagi memastikan penulis mengutamakan ilmu, pemikiran dan kebijaksanaan sewaktu berkarya. Mungkin ada cara yang lebih baik dilakukan oleh pengarang bagi mendidik masyarakat yang menghadapi masalah perkahwinan yang terhalang. Persoalan tersebut mungkin dapat diselesaikan melalui rundingan dan kesepakatan. 
GPB sememangnya bertujuan menonjolkan tema-tema yang berunsur nasihat, ihsan, kemanusiaan, kasih sayang, hikmah dan sebagainya. Baharuddin Ahmad (1992:71), menyatakan bahawa ilmu yang menjadi asas untuk mengenal Tuhan meliputi penentuan akal, pengawalan tindakan dan pengawasan tindakan manusia. Tindakan Jamjin yang tidak mampu menghalang emosi daripada terus berkahwin secara sendiri adalah salah dan beliau sebenarnya boleh memikirkan alternatif yang lain.

Perkahwinan campur yang berlaku antara Jamjin dan Mawar turut menonjolkan ketegangan atau akibat yang fatal. Selain daripada jalan cerita yang menimbulkan konflik dan bentuk ketegangan antara dua etnik yang berlainan agama, tindakan Imam Lagung yang membiarkan, melepaskan atau tidak mempedulikan masalah anaknya yang berhasrat mengahwini seorang wanita yang belum memeluk Islam adalah salah di sisi agama. Imam digambarkan menghalau Jamjin keluar daripada kampung mereka di Pirasan. Tindakan Imam yang membiarkan anaknya berkahwin sendiri mendorong Jamjin dan Punti dalam tragedi pendustaan agama yang dianggap lebih serius, iaitu zina sedangkan di awal cerita Imam Lagung digambarkan melaksanakan peraturan mengikut agama, iaitu hukuman sebat bagi pesalah zina. Situasi ini memperlihatkan walaupun pemikiran pengarang tentang Islam kelihatan tegar, gangguan terhadap falsafah Islam itu juga sedikit goyah melalui paparan perkahwinan kedua-dua mempelai tersebut. Imam tersebut gagal melaksanakan tanggungjawabnya sebagai seorang imam dan ayah yang perlu melindungi dan membimbing anaknya ke jalan yang benar. Imam Lagung bukan sahaja tidak membimbing pasangan tersebut malah, mereka dihalau keluar daripada kampung.

Hal ini turut ditimpakan kepada watak Boyong dan Kunang yang melaksanakan adat perkahwinan menurut tradisi Dayak Kayan. Proses perkahwinan Boyong dan Kunang dilaksanakan di petempatan masyarakat Dayak yang belum beragama Islam. Mereka tidak dinikahkan secara Islam melainkan digambarkan berkahwin secara adat tradisi. Selain daripada itu, Boyong yang beragama Islam terikat kepada tatacara adat, iaitu dilarang bersama isterinya selama tiga malam selepas dikahwinkan secara adat tradisi. Pada mulanya persepsi pembaca mengandaikan bahawa tempoh tiga hari tersebut mengambil kira perjalanan pulang Boyong ke kampung 
halaman. Namun, tanggapan itu tidak benar kerana tempoh tiga hari adalah syarat yang ditetapkan oleh tradisi Kayan, iaitu masyarakat diwajibkan mendengar segala bunyi binatang seperti rusa secara beramai-ramai. Jika hanya pengantin yang mendengarnya, pengantin perlu dipisahkan untuk tujuan tolak bala.

Berkemungkinan pengarang ingin menjelaskan tentang kedudukan Boyong yang jauh daripada kelompok masyarakat Islam Melanau dan dibolehkan untuk berkahwin secara animisme. Tetapi ia bukan dapat dijadikan alasan menikahkan kedua-dua pasangan tersebut dengan cara sewenang-wenangnya dan membelakangkan syariat Islam. Persoalan ini mengganggu gugat falsafah keagamaan yang cuba ditampilkan pengarang pada permulaan teks yang menunjukkan Boyong berjuang demi mempertahankan akidah Muslim. Bagi GPB, perkara ini tidak wajar dan bukan setakat memanipulasikan cerita tetapi memperkotak-katikkan agama. Adat tradisi yang diamalkan menjadi salah kerana disandarkan pada sesuatu kepercayaan yang akhirnya menjadi khurafat atau lebih bahaya lagi menyebabkan syirik atau menyekutukan Allah SWT.

Satu lagi perkara yang cuba ditonjolkan pengarang dalam kedua-dua novel ialah perjuangan atau semangat orang-orang muda dalam melestarikan hidup, mempertahankan maruah agama dan bangsa mereka. Boyong bersama rakan-rakannya berhadapan dengan bahaya dan kematian kerana menuntut tengkorak kepala datuk mereka yang telah dibunuh oleh suku Dayak. Boyong tidak mahu kepala datuk mereka yang telah dilarikan orang Dayak (Kelabit) disemadikan dengan cara kepercayaan animisme. Prinsip yang dipegang oleh Boyong sebagai etnik Melanau beragama Islam boleh disifatkan sebagai mempertahankan maruah agama dengan melakukan jihad fisabilillah. Hal ini selari dengan GPB, yakni berjuang bagi menonjolkan perjuangan menuntut kebenaran bagi umat Islam.

Bagi Boyong, tengkorak datuk mereka Syariff Hamid harus dikebumikan dengan cara Islam dan tidak layak untuk ditanam di tiang seri orang 'kafir' (Ngayau, hlm. 17). Boyong yang telah kehilangan rakanrakan akibat cubaan merebut kembali maruah agama mereka, sanggup pula menggadai nyawa, kembali semula ke kawasan rumah panjang suku 
kaum Kayan untuk mengambil tengkorak yang diletakkan di sebuah tempat khas di rumah panjang tersebut. Dia mahu rakan-rakannya yang telah terkorban disemadikan secara Islam. Demikian juga dengan Jamjin. Dia berusaha untuk mengebumikan isterinya Mawar (Punti) dengan cara Islam. Sungguhpun Maragang dan kuncu-kuncunya telah melarikan mayat Punti, Jamjin bertarung nyawa merampasnya kembali. Peristiwa tersebut menggambarkan bagaimana perjuangan watak menegakkan agama yang mendasari pemikiran pengarang dalam novel-novel tersebut. Hak jenazah atau mayat orang Muslim perlu dimandi, dikafan, disolat dan dikebumikan mengikut cara Islam.

Penyempurnaan mayat pula dalam hukum Islam adalah fardu kifayah. Menyempurnakan hak jenazah Muslim yang telah meninggal adalah wajib bagi sebahagian Muslim dan jika tidak ada sesiapa yang tidak mahu melaksanakannya, maka hukumnya adalah berdosa. Imam Lagung mewakili imam di Kampung Pirasan tidak mahu menyempurnakan mayat Mawar yang dianggapnya masih kafir. Oleh hal yang demikian, tindakan imam tersebut tidak menggambarkan Muslim sejati sungguhpun beliau adalah seorang imam. Sesuai dengan hakikat insan yang bermaksud pemahaman tentang hakikat penciptaan dan kejadian manusia di muka bumi ada diceritakan dalam al-Quran tentang permulaan kejadian Nabi Adam sebagai khalifah Allah SWT di muka bumi. Hal ini dikaitkan pula dengan konsep taklif, iaitu keterikatan (janji azali) manusia kepada Pencipta sebagaimana yang dijelaskan dalam hakikat insan. Oleh itu, setiap insan harus berfikir dan menilai menggunakan kelebihan akal yang dikurniakan Allah SWT kepada manusia supaya terhindar daripada perkara negatif.

Sesungguhnya tindakan yang dilakukan Imam Lagung tidak menerima Punti sebagai menantu dan tidak mahu menikahkan anaknya dianggap terlalu kasar dan tidak sepatutnya dilakukan bagi melaksanakan unsur dakwah. Tindakannya tidak menerima jenazah Mawar juga melipatgandakan lagi sifat tidak berperikemanusiaan beliau sebagai seorang yang berpendidikan agama. Beliau melaksanakan tanggungjawab sebagai imam yang melaksanakan hukum ke atas masyarakat lain tetapi mengetepikan tanggungjawabnya sebagai ayah dan imam yang wajar membantu orang lain, khususnya golongan mualaf. Agama tidak mempunyai 
batasan sempadan. Sungguhpun Jamjin membawa isterinya dari Lumatok, ia boleh disempurnakan di Kampung Pirasan dan bukannya dipulangkan kepada keluarganya yang masih belum Islam. Reaksi dan tindakan yang dilakukan imam itu memperlihatkan bahawa Bagaton lebih memfokuskan nilai cerita yang menjadi sebab akibat tindakan setiap wataknya tanpa mengangkat nilai ilmu bagi memberi kefahaman dan penjelasan yang betul kepada pembaca. Sungguhpun nilai cerita yang menjadikan karya tersebut sarat dengan konflik, tindakan pengarang memfokuskan tindakan imam untuk bertindak lebih wajar telah mengurangkan nilai ilmu yang ada dalam novel Bagaton.

Pemikiran lain yang turut dipaparkan dalam novel tersebut ialah tentang kemanusiaan dan kasih sayang sesama insan. Contohnya novel Ngayau yang memperlihatkan sungguhpun pertarungan dan pembunuhan sesama insan, ia akhirnya menemui jalan perdamaian. Lolong dan Kasung yang bermusuhan akhirnya boleh berpimpin tangan dan saling membantu demi kesejahteraan bangsa mereka, bangsa suku Kayan yang telah bermusuh sejak sekian lama. Demikian pula harmoninya kehidupan Boyong dan Kunang yang berlainan agama dan suku kaum. Mereka dapat menjalinkan persefahaman dan kemakmuran kehidupan berlainan bangsa dan agama melalui perkahwinan campur. Inilah hasrat murni yang cuba diterapkan oleh pengarang melalui Ngayau, dengan menggunakan metode atau kaedah permusuhan antara kaum bagi mencapai matlamat memberikan nilai murni kepada pembaca sejajar dengan konteks masyarakat Sabah. GPB sememangnya ingin menonjolkan sifat perikemanusiaan dan persefahaman sesama insan.

Perkara ini berlainan dengan pengalaman yang dialami keluarga Imam Lagung. Walaupun berada di kawasan atau daerah yang sama, suku kaum Dusun dan Bajau yang berlainan agama di Sabah digambarkan tidak sependapat, tidak menghormati antara satu sama lain, berdendam dan mempunyai perasaan hasad dengki atas kejayaan dan kemampuan orang lain. Pengarang menceritakan kegiatan ekonomi Maragang sebagai penternak binatang seperti kerbau dan babi. Imam Lagung pula menjalankan perniagaan menjual garam di kawasan perdesaan tersebut. Disebabkan dengki khianat, Maragang menuduh Imam Lagung mencuri kerbau dan dijadikan hamba dan disogit (denda). Maragang telah menghukum Imam 
Lagung bekerja di ladang babi dan perkara itu benar-benar menyakitkan hati Imam Lagung kerana babi adalah haram bagi umat Islam. Baginya, tindakan Maragang bukan hanya menghina beliau tetapi turut menghina orang Islam.

Peristiwa itu telah menjadikan Imam Lagung sangat marah dan berdendam kepada Maragang. Kesan kejahatan yang dilakukan oleh Maragang ke atas Imam Lagung begitu mendalam sebagaimana kata-kata dari petikan berikut:

"Benak ini masih menggambarkan secara jelas peristiwa itu. Ulang imbas bayangnya amat ketara seperti semalam saja berlaku. Ibarat luka darahnya akan meleleh kembali bila tersentuh. Aduh, anakku amat perit rasanya!.” (Bagaton, 1988: 8).

Islam memang melarang umatṇya berdendam. Namun demikian, tindakan Maragang yang menghina kesucian agama Islam menyebabkan Imam Lagung terluka. Umum mengetahui bahawa agama Islam mangharamkan babi kepada orang Islam, sama ada memelihara, menyentuh apalagi memakannya. Melalui hukuman tersebut, penulis seolah-olah memprovokasi penentangan antara dua kaum yang berlainan kepercayaan dan agama. Perkara ini ada diterangkan dari petikan novel seperti berikut:

"Mereka tahu, dan mereka secara sengaja mahu merosakkan keyakinan, iman dan kepercayaan agama ayah, sebab mereka fikir mereka boleh lentur kepercayaan ayah semudah itu" (Bagaton, hlm. 10).

Watak Imam Lagung sebagai seorang imam diberikan gambaran sebagai seorang imam yang berpegang teguh kepada tali agama. Dia digambarkan berbudi pekerti dan baik kepada penganut agama Islam dan agama lain, khususnya kaum Bajau di daerah Pirasan. Namun pada satu peringkat, beliau telah diselewengkan daripada perwatakan yang sepatutnya beliau dicirikan. Beliau hanyut dalam emosi dendam dan sakit hati. Perbuatan ini amat bertentangan dengan GPB kerana penilaian mengikut gagasan ini hanya menerima penekanan terhadap unusr-unsur seperti kebaikan dan kemanusiaan. Tindakan Imam Lagung dan anaknya Jamjin dan Boyong pada akhirnya digambarkan penulis seolah-olah mengutamakan apa yang disebut sebagai perasaan atau emosi (khayalan kreatif) oleh gagasan ini. 
Sebaliknya, penulis harus menerapkan sifat bermaafan dan bertolak ansur serta muafakat untuk membentuk sebuah masyarakat yang harmoni. Penulis hanya mengemukakan sikap tenang dan bersabar atas penyeksaan konco-konco Maragang sepanjang dia (Imam Lagung) ditahan sebagai hamba. Namun, kesabaran imam tersebut tidak mampu dikawal ketika berhadapan dengan isu anaknya ingin berkahwin dengan Punti, hanya kerana dia adalah anak kepada musuhnya. Sebuah novel baik yang mengikut prinsip GPB adalah novel yang mampu memberikan unsur pengajaran kepada masyarakat berlandaskan ilmu yang benar, dilakukan secara bijaksana tanpa manipulasi emosi yang keterlaluan melalui watak-watak yang ditonjolkan.

\section{KESIMPULAN}

Kedua-dua novel yang dikaji berusaha untuk mengangkat nilai dakwah dan akidah Islam dalam kedua-dua novel tersebut. Penjelasan berkenaan GPB yang digunakan untuk menilai novel dengan mengambil kira prinsipprinsip dalam gagasan tersebut memperlihatkan bahawa kedua-dua novel cuba menerapkan unsur-unsur ilmu yang benar. Namun demikian, terdapat beberapa perkara yang akhirnya menjadikan kedua-dua novel menyimpang daripada landasan sebenar. Percanggahan dan pertembungan tersebut berlaku kerana kekeliruan dan kekaburan terhadap beberapa perkara pokok dalam syariat yang telah digariskan oleh Islam. Oleh hal yang demikian, ia memperjelaskan bahawa analisis menggunakan GPB menjelaskan bahawa kedua-dua karya lebih menitikberatkan cerita berbanding ilmu.

\section{RUJUKAN}

Abdul A'la. (1984). Dasar-dasar Islam. Bandung: Penerbit Pustaka. Amil Jaya. (1979). Ngayau. Kuala Lumpur: Dewan Bahasa dan Pustaka. Amil Jaya. (1988). Bagaton. Kuala Lumpur: Dewan Bahasa dan Pustaka. Baharuddin Ahmad. (1992). Sastera sufi. Kuala Lumpur: Dewan Bahasa dan Pustaka.

Hamka. (1977). Pandangan hidup Islam. Kelantan: Pustaka Aman Press Sdn. Bhd. 
Haron Din. (1991). Manusia dan Islam Jilid 2 \& 3. Kuala Lumpur: Dewan Bahasa dan Pustaka. (1970). English-Kadazan phrase book. Sabah: Borneo Literature Bureau.

Mahmoed Joenoes. (1968). Tafsir Quran Karim (Cetakan ke-12). Jakarta: Alma'arif.

Mohamed Asin Dollah. (1996). Psikologi Islam atau kerohanian Islam satu dilema. Dlm. Zakaria Stapa \& Mohamed Asin Dollah (Peny.), Islam Akidah dan Kerohanian, pp. 98. Bangi: Penerbit Universiti Kebangsaan Malaysia.

Mohd. Affandi Hassan. (1992). Pendidikan estetika daripada pendekatan tauhid. Kuala Lumpur: Dewan Bahasa dan Pustaka.

Mohd. Afandi Hassan, Ungku Mimunah Mohd. Tahir \& Mohd. Zariat Abdul Rani. (2008). Gagasan persuratan baru pengenalan dan penerapan. Bangi: Institut Alam dan Tamadun Melayu.

Mohd. Zariat Abdul Rani. (2004). Seksualiti dalam novel Melayu: Satu analisis teks berdasarkan persuratan baru. Tesis Sarjana. Bangi: Universiti Kebangsaan Malaysia, Kuala Lumpur.

Othman Ishak. (1979). Hubungan antara undang-undang Islam dengan undangundang adat. Kuala Lumpur: Dewan Bahasa dan Pustaka. 
